\title{
Internationalisering og progression
}

\author{
Lisanne Wilken, lektor ved Institut for Kultur og Samfund, Aarhus Universitet. \\ Hanne Tange, lektor ved Institut for Kultur og Globale Studier, Aalborg Universitet.
}

\section{Reviewet artikel}

I Danmark har vi traditionelt tænkt universiteternes femårige kandidatuddannelser som sammenhængende forløb, hvor den studerende gradvist opbygger en stadig mere specialiseret viden inden for et givet fagområde. Denne idé om progression er $i$ de senere år blevet udfordret fra flere sider. Især er progressionsidéen blevet diskuteret i forhold til tværfaglige uddannelsesforløb, men også de mange internationale uddannelser, der etableres, udfordrer den måde, hvorpå vi traditionelt har forstået progression $i$ det danske uddannelsessystem. På internationale kandidatuddannelser finder vi nemlig typisk både studerende, for hvem kandidatuddannelsen er en forlængelse af en grunduddannelse, og studerende, der har taget deres grunduddannelse et andet sted og muligvis endda $i$ et andet fag. I denne artikel undersøger vi, hvordan undervisere på kandidatuddannelser som både er tværfaglige og internationale forholder sig til progression. Artiklen er skrevet på baggrund af semistrukturerede interviews med undervisere fra tvarfaglige, internationale uddannelser ved Aarhus Universitet.

\section{Internationalisering og progression}

I Danmark har vi traditionelt opfattet universiteternes kandidatuddannelser som afslutningen på et femårigt studium, hvor de studerende gradvist tilegner sig større dybde og specialisering inden for et givet fagområde. I den definition, der gives på Forskningsministeriets hjemmeside, understreges det, at "[k]andidatuddannelserne skal bidrage til at udbygge den viden og de kvalifikationer, som den studerende har tilegnet sig gennem bacheloruddannelsen" samt, "at de studerende gennem faglig fordybelse videreudvikler deres kompetencer" (Forskningsministeriet, 2013). Idéen om progression mellem bachelor- og kandidatforløb er også bygget ind i de uddannelsesreformer, som er gennemført inden for det seneste tiår (Andersen, 2008:7). Her lægges der op til, at der skal ske en fremadskridende videns- og færdighedstilegnelse, hvor de studerende hele tiden udvider og uddyber den viden, de tidligere har tilegnet sig. Imidlertid er det ikke alle videregående uddannelsesforløb der uden videre passer ind i denne forestilling om progression. I de senere år er spørgsmålet om progression især blevet drøftet i forhold til de mange tværfaglige kandidatuddannelser, der er blevet etableret på landets universiteter. Her har et væsentligt tema 
været, i hvilket omfang de studerende på tværfaglige forløb har mulighed for at opnå en faglig dybde og et niveau, der kan stå mål med det, der opnås på enkeltfaglige kandidatuddannelser (ACE Danmark, 2013).

Diskussionen om tværfaglighed er vigtig, når man skal forholde sig til spørgsmål om progression i danske universitetsuddannelser, men tværfaglighed er ikke den eneste udfordring til progressionsidéen. I de senere år har danske universiteter gennemgået en høj grad af internationalisering. Det betyder, at en række universitetsuddannelser nu udbydes på engelsk og rekrutterer studerende, der har fået deres grunduddannelser på andre universiteter, i andre lande og ind imellem også i andre fag. Mange af de internationale uddannelser er oven i købet tværfaglige, hvilket betyder, at progression skal tænkes i forhold til en meget stor grad af diversitet. I det følgende undersøger vi med afsæt i data fra et forskningsprojekt om internationalisering af universitetsuddannelser i Danmark hvilke overvejelser undervisere på tværfaglige internationale kandidatuddannelser gør sig om progression.

Vi starter med en kort diskussion af, hvordan progression behandles i litteraturen om internationalisering af videregående uddannelser og en præcisering af, hvordan begrebet forstås i denne artikel. Dernæst følger nogle analysemetodiske overvejelser og endelig diskuterer vi hvordan undervisere på internationale uddannelser forholder sig til progression.

\section{Progression og internationalisering}

I de senere år har der været en voksende forskningsinteresse både for progression (fx Andersen, 2008; Nielsen \& Sarauw, 2012) og for internationalisering af universitetsuddannelser i Danmark (fx Wilken, 2007; Mortensen et al., 2012; Tange \& Jensen, 2012). Indtil videre har der dog ikke været fokus på progression i relation til internationalisering. Det skyldes muligvis, at internationaliseringsforskningen som felt stadig er domineret af forskere fra Storbritannien, USA og Australien, hvor man ikke i samme grad som i Danmark har tradition for at forstå kandidatuddannelser som en overbygning på de studerendes grundforløb. I internationaliseringsforskningen handler spørgsmål om faglig viden i stedet om, hvorvidt udenlandske studerendes kompetencer anerkendes af værtsinstitutionen (fx Volet, 1999; Singh, 2005), og om hvordan nogle udenlandske studerende placeres i rollen som fagligt "svage" eller "anderledes" (fx Singh \& Shrestha, 2008; Tange \& Jensen, 2013). Spørgsmålet om progression er imidlertid helt centralt for forståelsen af praksis på internationale uddannelser i Danmark, fordi den forventning om en fremadskridende videnstilegnelse, som er indbygget i forståelsen af uddannelsessystemet, udfordres af universiteternes ambition om at tiltrække flere udenlandske studerende. En sådan strategi betyder nemlig, at undervisere på internationale uddannelser i stigende grad skal kunne inkludere studerende med forskellige grunduddannelser og forholde sig til, om der er 
en bestemt grundviden, man kan bygge på. På internationale tværfaglige kandidatuddannelser kan diversiteten i de studerendes grunduddannelser være endog meget stor, fordi man her ofte sigter efter at rekruttere studerende fra forskellige discipliner. Netop på grund af den store diversitet i de studerendes faglige og uddannelsesmæssige baggrunde kan det, når man diskuterer progression i forhold til internationale uddannelser, være nyttigt at skelne mellem to forskellige former for progression, nemlig progression i udvikling af faglig viden (Meyer \& Land, 2005; Andersen, 2008) og progression i forhold til den implicitte viden, der er relateret til akademisk praksis (Gerholm, 1990; Ulriksen, 2009).

I analyser af det danske uddannelsessystem diskuteres progression ofte ud fra en taksonomisk forståelse af, at den viden og de færdigheder, studerende tilegner sig gennem uddannelsessystemet, bliver stadig mere komplekse (fx Andersen, 2008; Søndergaard et al., 2009). I de senere år har der dog været fokus på mismatch i progression mellem forskellige overgange i uddannelsessystemet (fx Søndergaard et al., 2009), hvilket antyder, at progression i praksis måske er mindre lineær, end hvad de senere års uddannelsesreformer lægger op til. Helt grundlæggende indebærer idéen om faglig progression dog, at det er den viden og de færdigheder, studerende allerede har tilegnet sig, der skal videreudvikles.

Progression handler ikke kun om eksplicit faglig viden. Diskussioner om progression bør også relateres til de studerendes socialisering ind i en akademisk praksis, hvorigennem de lærer at "gøre" deres studie på en legitim måde. Den svenske etnolog Thomas Gerholm har med inspiration fra Bourdieus uddannelsessociologi foreslået, at studerendes bemestring af et givet fags implicitte viden og praksis har stor betydning for, hvordan underviserne vurderer deres eksplicitte, faglige viden. I forbindelse med sin undersøgelse af ph.d-uddannelsen på svenske universiteter hævder han, at "failure to acquire (...) implicit knowledge is often taken as a sign of failure to have acquired the explicit knowledge itself" (Gerholm, 1990, s. 263). Gerholm tilføjer, at vurderingen af, hvorvidt man behersker "the cultural life in the discipline and the department functions as an informal sorting device often without the sorters and the sorted being aware of the fact" (ibid.).

Det er selvfølgelig ikke kun i forhold til internationalisering, at implicit viden og praksis kommer til at spille en væsentlig rolle i forhold til uddannelse og undervisning (se fx Hasse, 2002; Ulriksen, 2003). Men det bliver særligt tydeligt på internationale kandidatuddannelser, fordi undervisere her konfronteres med studerende, der allerede er socialiseret ind i en akademisk praksis, som ikke nødvendigvis stemmer overens med den, der gælder lokalt. Efter en kort introduktion til den undersøgelse, vi har foretaget, vil vi derfor se nærmere på, hvad undervisere på udvalgte kandidatuddannelser siger om progression. 


\section{Undersøgelsen}

Diskussionerne i denne artikel er baseret på data indsamlet i forbindelse med et FKK-finansieret forskningsprojekt om internationalisering af universitetsuddannelser i Danmark (http://internationalisering.au.dk). Undersøgelsens case er Aarhus Universitet, der gennem det seneste tiår har ført en ambitiøs internationaliseringspolitik med det formål at "markere universitetet som et ledende og synligt internationalt universitet" og at positionere det som en "central aktør på det internationale uddannelsesmarked" (AU, 2009, s. 2, 4). Som led i internationaliseringen har Aarhus Universitet øget antallet af engelsksprogede uddannelser især på kandidatniveau. 62 af universitetets 117 kandidatuddannelser udbydes i dag på engelsk. De mange engelsksprogede uddannelsestilbud har - sammen med effektiv markedsføring og placeringer højt på internationale rankinglister - ført til en vækst i antallet af internationale studerende (Wilken, 2013). Fra 2007 til 2011 voksede antallet af internationale fuldtidsstuderende på Aarhus Universitet fra 1254 til 2315, hvortil kommer godt 1000 udvekslingsstuderende (Styrelsen for Universiteter og Internationalisering, 2013, s. 23). De internationale studerende udgør hermed knap $10 \%$ af alle studerende ved universitetet. I samme periode har Aarhus Universitet prioriteret tværfaglighed (AU, 2011) og en række af universitetets nyere uddannelser, herunder de internationale, er tværfaglige.

I denne artikel trækker vi på 12 interviews med undervisere fra to tværfaglige, internationale kandidatuddannelser. Interviewene er hentet fra et delprojekt, der undersøger underviseres forståelse af faglige udfordringer og pædagogisk praksis i et internationalt læringsrum. Der er tale om 7 interviews med undervisere på uddannelse A, som er en tværfaglig uddannelse med bidrag fra Naturvidenskab, Samfundsvidenskab og Humaniora, og 5 interviews med undervisere på uddannelse $\mathrm{B}$, som kombinerer tre forskellige retninger inden for erhvervsøkonomi. Interviewene har formet sig som løst strukturerede samtaler med udgangspunkt i en interviewguide, der fokuserer på undervisernes praksis. Med inspiration fra Pierre Bourdieus (1990) og Theodore Schatzkis (2001) teorier om praksis er der i interviewene spurgt ind til såvel konkrete undervisningssituationer (klasseundervisning, gruppearbejde, projektarbejde, eksamen) som til undervisernes forståelser af de studerende. Interviewene har haft en varighed af $1 \frac{1}{2}$ til to timer og er foregået på dansk eller engelsk. Interviewene er transskriberet ad verbatim og efterfølgende kodet i Nvivo ud fra et slags grounded theory-princip (fx Corbin \& Strauss, 2007), hvis formål har været at identificere temaer i interviewmaterialet. Efterfølgende er de identificerede temaer blevet kategoriseret, således at vi kan undersøge, hvordan underviserne italesætter de to former for progression, der er skitseret ovenfor. 


\section{Analyse}

Som nævnt forstår vi progression i relation til både faglig viden og akademisk praksis. I analysen vil vi således først belyse, hvordan informanterne beskriver den faglige progression, dernæst hvilke praktiske færdigheder, de forventer af studerende på uddannelsen.

\section{Viden og progression}

Temaet viden og progression er interessant, fordi vi har med en type kandidatuddannelse at gøre, som er tænkt anderledes end den traditionelle femårige danske model. Både uddannelse A og B er fra starten tænkt som internationale, tværfaglige overbygningsuddannelser, hvor der optages studerende, som ikke nødvendigvis har fulgt en af institutionens egne bacheloruddannelser. Samtidig har man på begge uddannelser valgt at kombinere fagligheder på nye måder. På uddannelse A har man sammensat et forløb, der skal sætte de studerende i stand til at belyse et genstandsfelt ud fra naturvidenskabelige, samfundsvidenskabelige og humanistiske perspektiver. Det vil sige, at der lægges op til, at de studerende sætter den viden de har opnået på deres forskellige bacheloruddannelser i spil i samarbejder på tværs af fagtraditioner hjemmehørende på forskellige fakulteter. På uddannelse B har man valgt at kombinere tre fag inden for erhvervsøkonomi. Underviserne beskriver selv fagene som meget forskellige, men der er dog tale om områder, der alle berøres i et eller andet omfang på en erhvervsøkonomisk grunduddannelse. Der stilles altså ikke krav om, at studerende skal forholde sig til fag uden for hjemmefakultetet.

I forhold til opfattelsen af viden er særligt to temaer af betydning, nemlig hvad der kan forventes af viden hos de studerende, og hvad det betyder for det faglige niveau på uddannelsen. Hvad angår det første spørgsmål, deler informanterne generelt en oplevelse af, at deres uddannelse adskiller sig ved at være tværfaglig og international. Det stiller nogle krav med hensyn til det faglige indhold og niveau, som en informant fra uddannelse B forklarer:

"But I think now here, as soon as there is some diversity, and that is always the case even if it is only a few, and even in the other programs, I guess, like the [Name] program where there is less international students, maybe, but there is still some diversity and some, also Danish students coming from other universities and so. I would always start like this, the first two weeks kind of repetition for some, but to make sure that everybody is somehow on the same page and not lost from the beginning."

En sådan tilgang bygger på en forventning om, at de studerende allerede har et vist kendskab til grundprincipper inden for kandidatuddannelsens område, og at et repetitionsforløb derfor kan køres relativt hurtigt. Med andre ord tages der godt nok 
højde for, at de studerende rent fagligt kan starte forskellige steder, men fordi alle har en erhvervsøkonomisk baggrund, regner underviserne også med, at de hurtigt kan indhente, hvad der eventuelt "mangler" af faglig indsigt.

Til sammenligning oplever en del undervisere fra uddannelse A en større afstand mellem den faglige baggrund, de studerende kommer med, og de traditioner, de selv repræsenterer. Fordi uddannelse A trods ambitionen om at optage studerende fra alle de repræsenterede fag i praksis primært optager studerende med en samfundsfaglig eller humanistisk bachelor bliver problemet særlig tydeligt for undervisere fra naturvidenskab, hvilket også skinner igennem i interviewene, hvor de studerende karakteriseres som værende "ikke [naturvidenskab]". Det giver nogle problemer i forhold til undervisningen, hvor underviserne skal forsøge at finde et niveau, der passer til en kandidatuddannelse samtidigt med, at de må forholde sig til, at de studerende kan have et andet fagligt udgangspunkt end det, der kendes fra egne bachelorforløb. En informant fortæller:

"[I] hvert fald havde [jeg] svært ved at finde ud af om de, om jeg ramte niveauet rigtigt, ikke? Og også fordi at til at starte med, vi havde jo bare sat niveauet alt for højt. Også selv om at vi jo godt var klar over, at de jo ikke var [fra Naturvidenskab], så vi nok ikke skulle forvente det helt store. Men det er altså alligevel / det blev jeg lidt overrasket over. For jeg har alligevel undervist på 3. semester en del år ... Og der må man sige, der skulle man altså sænke niveauet yderligere."

Undervisere fra Humaniora og Samfundsvidenskab oplever ikke i samme grad problemer med at gennemskue hvilket niveau eller indsigt, de kan forvente af de studerende. Det skyldes sandsynligvis, at disse informanters faglighed ligger tættere på de studerendes, hvilket giver mulighed for at inddrage metoder og begreber, som er genkendelige for de studerende. Her oplever man således en vis grad af faglig progression.

\section{Socialisering og akademisk praksis}

Mange af de undervisere, vi har talt med, har en personlig erfaring med tværfaglighed og i interviewene reflekterer de over nødvendigheden af at være meget eksplicitte, når det gælder ontologier og epistemologier og at synliggøre de akademisk praksisser, der ellers ofte tages for givet inden for bestemte fag. Det virker således som om der foregår et meget stort arbejde med at tydeliggøre hvilke arbejdsformer, der er legitime og ønskværdige, ligesom der afsættes ressourcer til at præsentere de metoder, der er vigtige for, at de studerende kan klare sig på uddannelsen. 
De fleste informanter udtrykker en idé om, at der på danske kandidatuddannelser er visse konventioner, der bare skal læres. Specielt i forhold til kurser, hvori der indgår skriftligt arbejde, henvises der til en særlig "dansk" tradition, som udenlandske studerende ikke altid følger, og som af underviserne opleves som problemer med manglende kildekritik, selvstændighed og referencer. En del undervisning tilrettelægges derfor, så de studerende meget eksplicit indføres i "danske" arbejdsformer. En informant forklarer eksempelvis, hvordan en skriftlig opgave blev indført på hans fag, fordi de udenlandske studerende skal lære at følge danske normer:

"[H]ele det projekt bygger på, at de udenlandske studerende, øh ..., har problemer med at skrive en hovedopgave. Det var det vi oplevede i hvert fald. Mange af dem har ikke skrevet en BA-opgave, de ved ikke hvad det vil sige at skrive en BA-opgave. Der er det danske system også meget rigidt. Der skal være en problemformulering, BAM BAM BAM BAM."

Også i forhold til gruppearbejde tænker flere socialisering som en tilnærmelse til dansk akademisk praksis. På uddannelse A vægtes denne arbejdsform højt på flere kurser, og informanter herfra giver da også udtryk for, at en vigtig del af de studerendes læring er at tilegne sig en sådan metode. På uddannelsen introducerer man gruppearbejdsformen allerede i introduktionsugen, og der arbejdes efterfølgende aktivt med formen på flere kurser, hvor informanterne beskriver en meget aktiv rolle i forhold til grupperne. På et enkelt kursus legitimeres denne praksis yderligere ved, at der til fagets mundtlige eksamen spørges ind til gruppeprocessen.

På en international uddannelse kan det muligvis opleves som et problem, at man socialiserer studerende ind i en akademisk praksis, som i forvejen må antages at være velkendt af de studerende, der er uddannet i det danske uddannelsessystem, fordi man herved giver en del af de studerende "hjemmebanefordel" (Wilken, 2007). En del af vores informanter forsøger at imødegå dette ved at indføre arbejdsformer, der må formodes at være nye for såvel lokale som for udefrakommende studerende, og som derfor i udgangspunkt stiller alle lige. To kurser på uddannelse A har valgt en sådan tilgang, der af en informant beskrives således:

"[H]ele kurset er bygget op om at, at så hører de noget om hvordan man laver et problemtræ når man skal, et objective tree, fordi vi bruger det der hedder Logical Framework Approach ... De hører lidt om baggrunden, og så gør de det selv. Så hører de om stakeholders. Så skal de finde dem i deres eget projekt. Så, ja, og de starter ud med at skrive noget project context, hvor de finder ud af noget om området. Så sådan, step by step, så bliver de ledt igennem, hvordan man udvikler sådan en project proposal". 
Her forventes det ikke, at de studerende har forhåndskendskab til metoden. I stedet arbejder man på faget med at etablere en ny akademisk praksis, som konsolideres på et senere kursus, hvor de studerende skal lave et projekt efter samme model. Interessant nok vælges denne tilgang på fag, hvor underviserne beskriver en høj grad af vidensmæssig asymmetri (Tange \& Kastberg, 2013). Her ser man, at internationale tværfaglige uddannelser motiverer underviserne til at nytænke deres akademiske praksis. Det sker imidlertid ikke nødvendigvis uden omkostninger, fordi det store arbejde med at eksplicitere og gentænke praksis tager tid fra andre aktiviteter, hvilket også påpeges af en enkelt informant.

\section{Konklusion}

Ovenstående analyse har vist, hvordan undervisere fra to internationale, tværfaglige uddannelser oplever og arbejder med udfordringer, der kan relateres til progression. Hvis vi med progression forstår en videreudvikling af de studerendes faglig viden, ser vi, hvordan informanterne forventer, at de kandidatstuderende i en eller anden udstrækning kommer med et fagligt fundament, som man kan bygge ovenpå. På tværfaglige uddannelser kommer de studerende imidlertid med forskellige fundamenter, og ikke overraskende ser vi, at jo større afstand, der er mellem undervisernes og de studerendes fagligheder, jo vanskeligere er det for underviseren at identificere, hvad der kan bygges på. En del undervisere udtrykker frustration over, at niveauet $\mathrm{i}$ disse sammenhænge er lavere end det, man finder på tilsvarende fag på monofaglige kandidatuddannelser. Til gengæld fremhæver de, at de studerende opnår en række "sidegevinster" i form af kompetencer i tværfagligt og multikulturelt samarbejde, som antages at være efterspurgte på et stadigt mere globaliseret arbejdsmarked. Der er således en spænding mellem en oplevelse af tab i forhold til progression i traditionel forstand og vinding i forhold til innovative måder at samarbejde om faglige problemstillinger på.

Hvad angår progression som socialisering ind i en bestemt praksis, er vores informanter opmærksomme på, at de møder studerende med andre erfaringer, og at der skal være mulighed for, at disse kan tilegne sig de praktiske færdigheder og metoder, der kendes fra danske uddannelsesforløb. Begge uddannelser har således indført projektforløb, gruppearbejde, skriftlige opgaver, seminarer og lektiecaféer, hvis formål er at socialisere internationale studerende ind i noget, der forstås som danske arbejdsformer og/eller at skabe helt nye rammer for tværfagligt, internationalt samarbejde. I analysearbejdet med interviewene har det været påfaldende, at vores informanter, som ellers er meget reflekterede ift. nødvendigheden af at eksplicitere ontologi, epistemologi og praksis, ikke forholder sig eksplicit til, om man kan inkludere og dermed videreudvikle de praksisser, som de studerende har indlært på deres foregående uddannelser andre steder. Et af de andre delprojekter i vores projekt ser netop på den problemstilling. Men det bliver der skrevet om i en anden artikel. 
Lisanne Wilken er uddannet antropolog, dr. phil. og nu tilknyttet kandidatuddannelsen i Europastudier, Aarhus Universitet, hoor hun varetager undervisning $i$ analyse af kultur og samfund $i$ Europa. Et af forfatterens fokusområder har været udviklingen af Europastudier som international uddannelse, og hun modtog i 2013 Aarhus Universitets Jubilæumsfonds Pædagogiske Pris for dette arbejde. Hun har udgivet artikler om kulturel viden $i$ et globalt læringsrum og er p.t. involveret $i$ et FKK-finansieret projekt, der har til formål at afdække studerendes baggrund og motiver for at vælge en international uddannelse i Danmark.

Hanne Tange er tilknyttet uddannelsen i Engelsk og International Virksomhedskommunikation, Aalborg Universitet, hoor hun underviser og vejleder inden for området interkulturel kommunikation. Forfatteren er cand.mag. i Engelsk og Etnologi og har arbejdet med internationalisering siden 2002. Hun har udgivet en række artikler om sproglige og interkulturelle temaer relateret til internationalisering og er p.t. involveret $i$ et FKK-finansieret forskningsprojekt, der undersøger akademisk viden og pædagogisk praksis på internationale kandidatuddannelser i Danmark.

\section{Litteratur}

ACE Danmark (2013). Tværfaglighed på dagsordenen - udfordringer og potentialer. Ace Danmark.

Andersen, H. L (2008). Taksonomiske grundbegreber og progression i læring. I: Andersen (red.). Bevidsthed om læring i uddannelserne: progression, portfolio og entrepreneurship. Arbejdspapir for center for undervisningsudvikling. Aarhus Universitet.

AU (2009). Internationaliseringsstrategi 2009-2013. www.au.dk (besøgt 15.05.2013)

AU (2011). Den faglige udviklingsproces, Aarhus Universitet. Aarhus Universitet.

Bourdieu, P. (1990). The logic of practice. Cambridge: Polity Press.

Corbin, J. \& Strauss, A. (2007). Basics of qualitative research: Techniques and procedures for developing grounded theory. Thousand Oaks, CA.: Sage.

Forskningministeriet (2013). Bachelor- og Kandidatuddannelser. Downloaded 15. maj 2013 fra www.fivu.dk.

Gerholm, T. (1990). On Tacit Knowledge in Academia. European Journal of Education, 25 (3): 263-271.

Hasse, C. (2002). Kultur i bevxgelse. Fra deltagerobservation til kulturanalyse - $i$ det fysiske rum. Frederiksberg: Samfundslitteratur.

Meyer, J. F. \& Land, R. (2005). Threshold concepts and troublesome knowledge: Epistemological considerations and a conceptual framework for teaching and learning. Higher Education, 49 (3): 373-388.

Mortensen, J. et al. (2012). Uddannelse on the move - transnational studentermobilitet og uddannelseskvalitet. I: Andersen \& Jacobsen (red.). Uddannelseskvalitet $i$ en globaliseret verden. Vidensøkonomiens indtog $i$ de videregående uddannelser. Frederiksberg: Samfundslitteratur. 
Nielsen, G. \& Sarauw, L. L. (2012). Globalisering som spørgsmål: modulisering og kompetencetænkning som svar? I: Andersen \& Jacobsen (red.). Uddannelseskvalitet $i$ en globaliseret verden. Vidensøkonomiens indtog $i$ de videregående uddannelser. Frederiksberg: Samfundslitteratur.

Schatzki, T., Knorr-Cetina, K. \& Savigny, E. von (eds.) (2001). The Practice Turn in Contemporary Theory. London: Routledge.

Singh, M. (2005) Enabling Transnational Learning Communities: Policies, Pedagogies and Politics of Educational Power. I: P. Ninnes and M. Hellstén (eds.). Internationalizing Higher Education. Dordrecht: Springer.

Singh, M. \& Shrestha, M. (2008). International Pedagogical Structures: Admittance into the Com-munity of Scholars via Double Knowing. I: Hellstén and Reid (red.). Researching International Pedagogies. Dordrecht: Springer.

Styrelsen for Universiteter og Internationalisering (2013). Rapport om Aarhus Universitet. fivu.dk (hentet marts 2013).

Søndergaard, B. D. et al. (2009). Overgangsproblemer som udfordringer i uddannelsessystemet. Forskningsrapport, Aarhus Universitet.

Tange, H. \& Jensen, I. (2012). Good teachers and deviant learners? The meeting of practices in university level international education, Journal of Research in International Education, 11(2).

Tange, H. \& Kastberg, K. (2013). Coming to terms with double knowing: an inclusive approach to international education. International journal of inclusive education, 17(1).

Ulriksen, L (2009). The Implied Student. Studies in Higher Education, 34(5).

Ulriksen L. (2003). Hvad skal de studerende lære i fysik? Et lærerperspektiv. I: N. O. Andersen \& K.B. Laursen (red.). Studieforløbsundersøgelser i naturvidenskab. En antologi. Center for naturfagenes didaktik. Københavns Universitet.

Volet, S. (1999). Learning across cultures: appropriateness of knowledge transfer. International Journal of Educational Research. 31(7): 625-643

Wilken, L. (2007). Kulturforståelser og kapitalmøder i det internationale klasseværelse. Tidsskriftet Antropologi. 56: 135-157

Wilken, L. (2013). Navigating the global space of tertiary education - an exploration of the educational strategies of mobile students choosing to attend lesser known universities abroad. Paper presented at the ISA Annual Convention. San Francisco. 